\title{
First record of Triatoma maculata (Erichson, 1848) (Hemiptera: Reduviidae:Triatomini) in the municipality of Riohacha, La Guajira - Colombia
}

\author{
Edith Natalia Gómez-Melendro ${ }^{1}{ }^{*}$, Carolina Hernández ${ }^{2}$, Catalina González-Uribe ${ }^{1}$ and Helena Brochero ${ }^{3}$ \\ 1 Programa ECOSALUD ETV Colombia, Centro de Estudios e Investigación en Salud (CEIS), Fundación Santa Fe de Bogotá, Bogotá, Colombia \\ 2 Red Chagas Colombia, Grupo Parasitología, Instituto Nacional de Salud, Bogotá, Colombia \\ ${ }^{3}$ Facultad de Ciencias Agrarias, Universidad Nacional de Colombia, Bogotá, Colombia
}

Edited by:

Juan-Carlos Navarro, Universidad Central de Venezuela, Venezuela

Reviewed by:

Leidi Maira Herrera, Fundação Oswaldo Cruz (Fiocruz), Brazil

Elis Jose Aldana, Universidad de Los Andes, Venezuela

*Correspondence:

Edith Natalia Gómez-Melendro,

Centro de Estudios e Investigación en Salud (CEIS), Fundación Santa Fe de

Bogotá, Sede Edificio Fundacional,

Tercer Piso, Carrera 7 B No. 123 - 90,

Bogotá, Colombia

e-mail: natalia.gomez@

ecosaludetvcolombia.org
Introduction: Knowledge of vector insect species, their habitat, and geographical distribution is crucial for determining the risk of transmission of the etiological agents that cause disease in humans, which allows defining strategies for prevention, surveillance, and control in line with the characteristics of each area.

Objective: To determine the presence and public health importance of vectors of Chagas disease in the indigenous settlements of Marbacella and El Horno of the Wayúu ethnic group in the municipality of Riohacha, La Guajira, Colombia.

Materials and Methods: From active search, installation and inspection of biosensors, and occasional catches, Hemiptera: Reduviidae: Triatomini were collected intra and in the peridomicile housing of the indigenous settlements of El Horno and Marbacella of the Wayúu ethnic group. Indices of intra and peridomestic infestation, colonization, density, dispersion, and natural infection with Trypanosoma cruzi Chagas, 1909 were calculated.

Results: $79.6 \%(n=90)$ of the specimens were collected in the peridomicile and $20.3 \%$ $(n=23)$ in the intradomicile, all corresponding to Triatoma maculata (Erichson, 1848). The natural infection indices with T. cruzi accounted for $43.5 \%$ for Marbacella and $36 \%$ for El Horno.

Conclusion: This is the first reported capture of individuals of $T$. maculata, considered a secondary vector of Chagas disease in Colombia, naturally infected with $T$. cruzi in the municipality of Riohacha expanding the geographical distribution of the species in the department of La Guajira.

Keywords: Chagas disease, vector indices, Wayúu ethnicity, Triatomini

\section{INTRODUCTION}

Chagas disease is a parasitic disease caused by Trypanosoma cruzi Chagas, 1909, mainly transmitted by blood-sucking insects belonging to the subfamily Triatominae (Hemiptera) (1). It is endemic in 21 countries in the Americas, and it is considered that between 18 and 20 million people are infected and 100 million are at risk of acquiring infection (2). American trypanosomiasis in Colombia is considered a public health problem because it is estimated that about eight million people are exposed to disease transmission and between 700,000 and 1,200,000 are infected with the parasite $(3,4)$.

In Latin America, the transmission of T. cruzi particularly occurs in rural areas, where triatomines have adapted to human habitat due to bioecological, political, socio-economic, and cultural factors. Rhodnius prolixus Stal, 1859, Triatoma dimidiata Latreille, 1811 and Triatoma infestans Klug, 1834, have represented, in terms of parasitological, epidemiological, and public health, the most important vectors in the transmission of Chagas disease $(5,6)$. In Colombia, $R$. prolixus and T. dimidiata are considered as major vectors because they are widely distributed and have high indices of house infestation, colonization, and natural infection with $T$. cruzi $(4,7,8)$. However, in areas where these species are not domiciled but have had outbreaks of the disease, studies have suggested the participation of secondary vectors such as T. maculata (9-11), Rhodnius pallescens Barber, 1932 (12), Eratyrus cuspidatus Stal, 1859 (13) and Panstrongylus geniculatus Latreille, 1811 (14). P. geniculatus was indicted in a major acute outbreak of Chagas disease in the Colombian Orinoco in 2014 (15).

In the municipality of Riohacha, La Guajira Department were recorded $R$. prolixus, T. maculata, and T. dimidiata with house infestation indices of $12.28 \%$ and naturally infected with Trypanosoma rangeli Tejera, 1920 and T. cruzi, respectively, with the R. prolixus $(79.27 \%)$ and T. maculata $(23.37 \%)$ populations being the most abundant in intradomiciliary environments, suggesting that this area of the country has optimal biological and ecological 
factors for the presence of important epidemiological triatomine bugs in human habitats (16). Because $44.9 \%$ of the human population in this municipality is indigenous (17), mainly of the Wayúu ethnic group, there are characteristics and socio-cultural practices in rural areas, which combined with the above could increase the level of risk of vectorial transmission of T. cruzi in the municipality of Riohacha.

In this context, the aim of this study was to determine the presence and public health importance of vectors of Chagas disease in the indigenous settlements of Marbacella and El Horno of the Wayúu ethnic group in the municipality of Riohacha, La Guajira, Colombia.

\section{MATERIALS AND METHODS \\ STUDY AREA}

The municipality of Riohacha, the capital of the department of La Guajira, is located on the Colombian Caribbean coast (Figure 1). The locations correspond to the indigenous settlements of El Horno $\left(11^{\circ} 30^{\prime} 16.35^{\prime \prime} \mathrm{N}\right.$ and $\left.72^{\circ} 59^{\prime} 21.31^{\prime \prime} \mathrm{W}\right)$ and Marbacella $\left(11^{\circ} 30^{\prime} 24.5^{\prime \prime} \mathrm{N}\right.$ and $\left.72^{\circ} 59^{\prime} 09.7^{\prime \prime} \mathrm{W}\right)$ situated at
$7.18 \mathrm{~km}$ from the Riohacha city center (Figure 1). The indigenous settlements are inhabited by about 300 members of the Wayúu ethnic group who are mainly engaged in fishing, making crafts, and grazing goats. The area corresponds to Tropical Dry Forest (Bs-T) $(18,19)$ with preferentially herbaceous vegetation, an average annual temperature of $28.2^{\circ} \mathrm{C}$ (minimum $23.4^{\circ} \mathrm{C}$, maximum $33.2^{\circ} \mathrm{C}$ ), relative humidity ranging between 59.3 and $77.5 \%$, and an annual bimodal rainfall regime, with the first rainy season between the months of April and June and another more representative period in the months of September and October, with rainfall between 700 and 2,000 $\mathrm{mm}$ (20-23).

\section{ENTOMOLOGICAL MATERIAL}

Three entomological surveys were performed during dry season (May, June and July 2013) and one during rainy season (September-October 2013) to search for feces, exuviae, eggs, immature, and adult forms of Hemiptera: Reduviidae: Triatomini, associated with the dwellings in the indigenous settlements of Marbacella and El Horno in Riohacha. Each sampling included

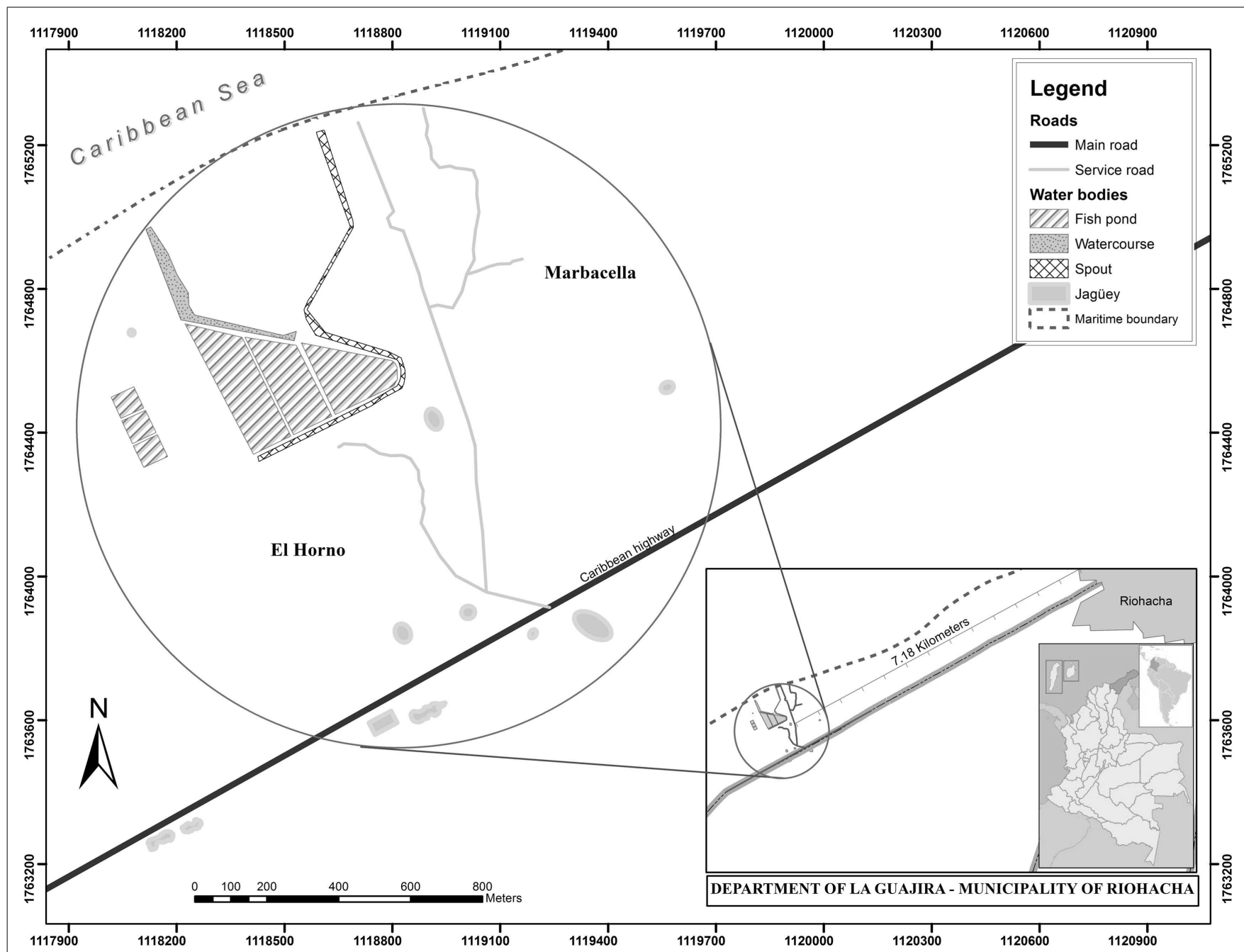

FIGURE 1 | Geographical location of El Horno and Marbacella settlements, Riohacha, La Guajira, Colombia is shown 
direct search in each house following the National Protocols of Entomological Surveillance (4); setting of Maria sensor type traps (24); and training people in the community for triatomine recognition.

The search was performed directly inside the houses examining the furniture, appliances, clusters of objects, cracks in walls and other places with favorable conditions for the presence of these insects, and around the homes inspecting kitchens, henhouses, pens, woodpiles, shady arbors, and animal nests $(4,24)$. Maria sensor type traps $(n=20)$ were installed at a height of $1.50 \mathrm{~m}$ from the floor, on the inside walls of randomly selected houses at each sampling, participation workshops were held for residents of communities to recognize the epidemiologically relevant triatomine species reported for the area and the invitation was to actively search and deliver entomological material collected. For this, full-size photographs of insects were used as well as entomological material from colony, pin mounted, and properly labeled. Biosafety standards for handling insects were emphasized and latex gloves, masks, entomological tweezers, and labeled bottles for data collection were delivered. In all cases, the insects were collected in plastic vials labeled with the catch information for each sampling method and were transported to the Laboratory of Entomology - Genetics Area of Economic Interest Insects, Faculty of Agricultural Science, Universidad Nacional de Colombia.

The taxonomic identification of immature stages and adults was based on morphological characters, including male genital specimens (6). The determination of the natural infection with $T$. cruzi was performed by optical microscopy inspection in $0.9 \%$ saline of the content of the distal portion of the insect gut. Also parasitic DNA detection was performed by polymerase chain reaction (PCR) amplification of a satellite nuclear region with cruzil primers (5'ASTCGGCTGATCGTTTTCGA3 ') and cruzi2 (5'AATTCCTCCAAGCAGCGGATA3') from abdomen of representative T. maculata specimens of each home. PCR was performed by initial denaturation of $94^{\circ} \mathrm{C}$ for $5 \mathrm{~min}$ followed by 40 cycles of $94^{\circ} \mathrm{C}$ for $1 \mathrm{~min}, 64^{\circ} \mathrm{C}$ for $30 \mathrm{~s}$, and $72^{\circ} \mathrm{C}$ for $1 \mathrm{~min}$. The PCR products were analyzed by electrophoresis in $2 \%$ agarose gels stained with GelRed (Biotum) (25).

For each indigenous settlement the following indices were calculated: intra and peridomestic infestation; colonization; infection; dispersion; and density, all in accordance with the guidelines of the Pan American Health Organization (PAHO) (26).

\section{ETHICAL ISSUES}

The project was approved by the Research Ethics Corporate Committee of the Fundación Santa Fe de Bogotá. The insect collection was conducted by officials from the Health Office of the department of La Guajira; researchers at the Fundación Santa Fe de Bogota, and Universidad Nacional de Colombia, as well as by citizens of the community who were trained to perform these activities and signed an informed consent where they were explained the objectives, risks, and benefits of the activity. The heads of households where the direct search for triatomines and installation of Maria sensors were conducted were informed of the purpose of the study, identifying their benefits and risks and were asked to consent to the development of the activities. The results obtained were shared with the Health Office of the department and the community of the indigenous settlements of El Horno and Marbacella of the Wayúu community of Riohacha, La Guajira.

\section{RESULTS}

A total of 68 homes out of $75(90.7 \%)$ were inspected due to the reluctance of the inspections by some heads of household. Direct search and occasional catches evidenced the presence of Hemiptera: Reduviidae: Triatomini in 16 homes using an accumulated capture effort of 80 man-hours during dry season and 16 man-hours in the rainy season (Figures 2 and 3). Thirtyfive adults, 63 nymphs, and 14 nymph exuviae were collected in various development stages and a wing, all from T. maculata (Table 1).

Out of 113 collected specimens, 79.6\% $(n=90)$ were collected in the peridomicile and $20.3 \%(n=23)$ in the intradomicile (Figures $\mathbf{2}$ and $\mathbf{3}$ ), in both cases mainly related to poultry rest and shelter areas and nests. No flagellar parasitic forms to T. cruzi were observed in the specimens where inspection by light microscopy $(n=16)$ was performed. However, in 19 of the 32 specimens of T. maculata analyzed by molecular biology techniques, a band of $166 \mathrm{bp}$ for the nuclear satellite DNA of T. cruzi (Figure 4) was seen. Table 2 shows the vector indices calculated for each indigenous settlement from the data collected.

\section{DISCUSSION}

T. maculata is one of the species of the Triatoma genus with the greatest geographical distribution in Colombia, being recorded in 11 departments located in the regions of the Orinoco plains and the Caribbean plains $(4,7)$. The department of La Guajira registers T. maculata in the municipalities of Maicao, Barrancas, El Molino, Fonseca, Hato Nuevo, Maicao, San Juan, Urbilla, and Villanueva (7, $8,16)$. The results of this study extend and update the geographic distribution of the species in the department, reporting it for the first time in the municipality of Riohacha.

T. maculata was the only species recorded in all samples taken in the indigenous settlements of Marbacella and El Horno, a finding that is consistent with that reported in other studies where the predominance of this species is observed in regions with temperatures ranging between 22 and $25^{\circ} \mathrm{C}$, rainfall between 1,500 and $2,000 \mathrm{~mm}$ annually and vegetation consisting mostly of scrub and thorn $(9,10,27,28)$.

Overall, T. maculata showed greater abundance in peridomestic spaces associated with henhouses, pets rest areas, and shelters, with infestation indices identical for both indigenous settlements. This biological preference continues in different geographical locations in Latin America $(6,10,16,27,29-31)$, which is explained due to the preference for ornithophilic-type eating habits that could be conditioning their biological behavior (32). However, the population density ( 0.8 for Marbacella and 4.2 for El Horno) and dispersion (21.6 and 33.3, respectively) of the species in this area may be associated with processes of high intraspecific competition due to the search for blood supply and the degree of anthropic disturbance (33), revealing a significant population dynamics resulting in the mobility of the species into different environments. 


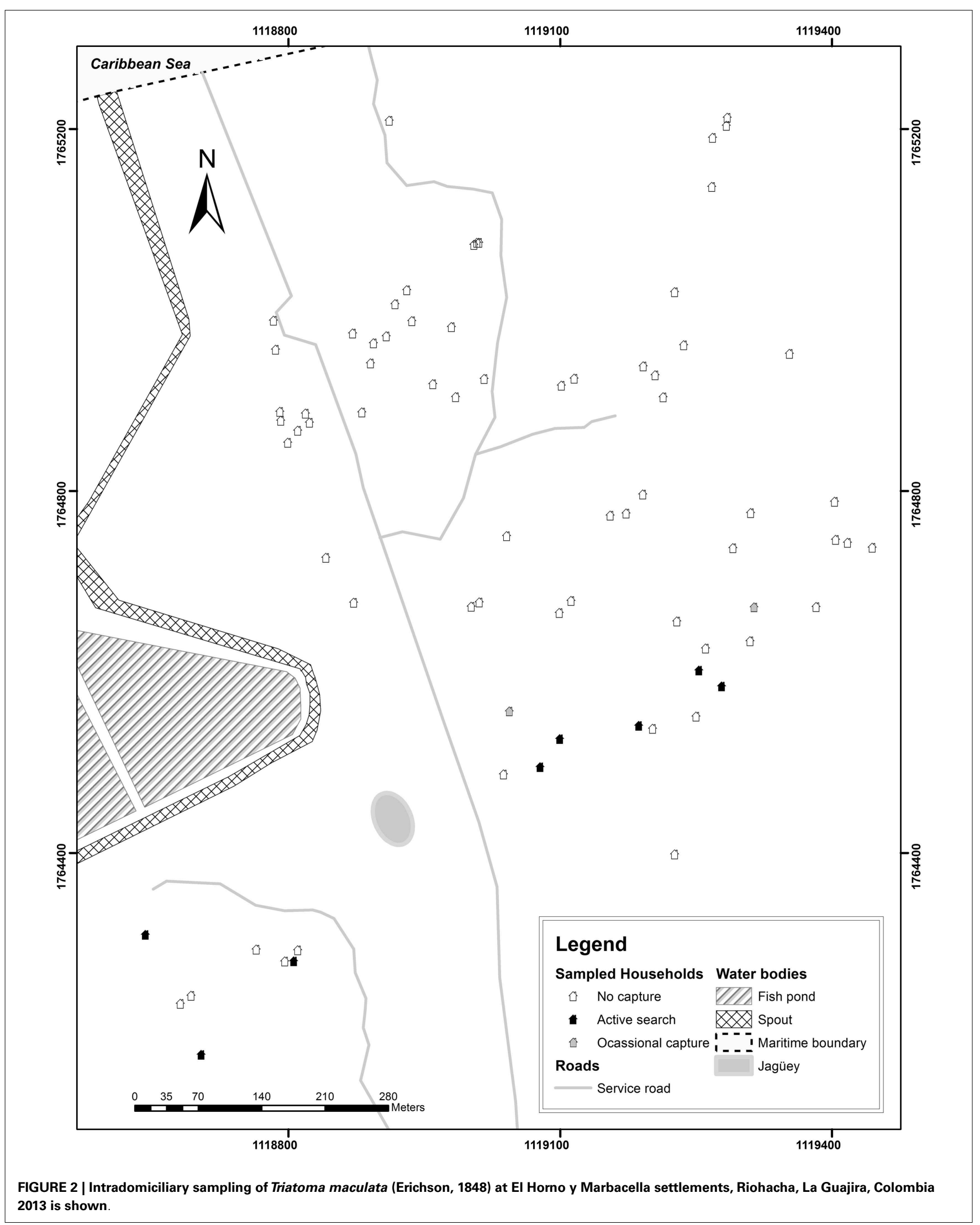




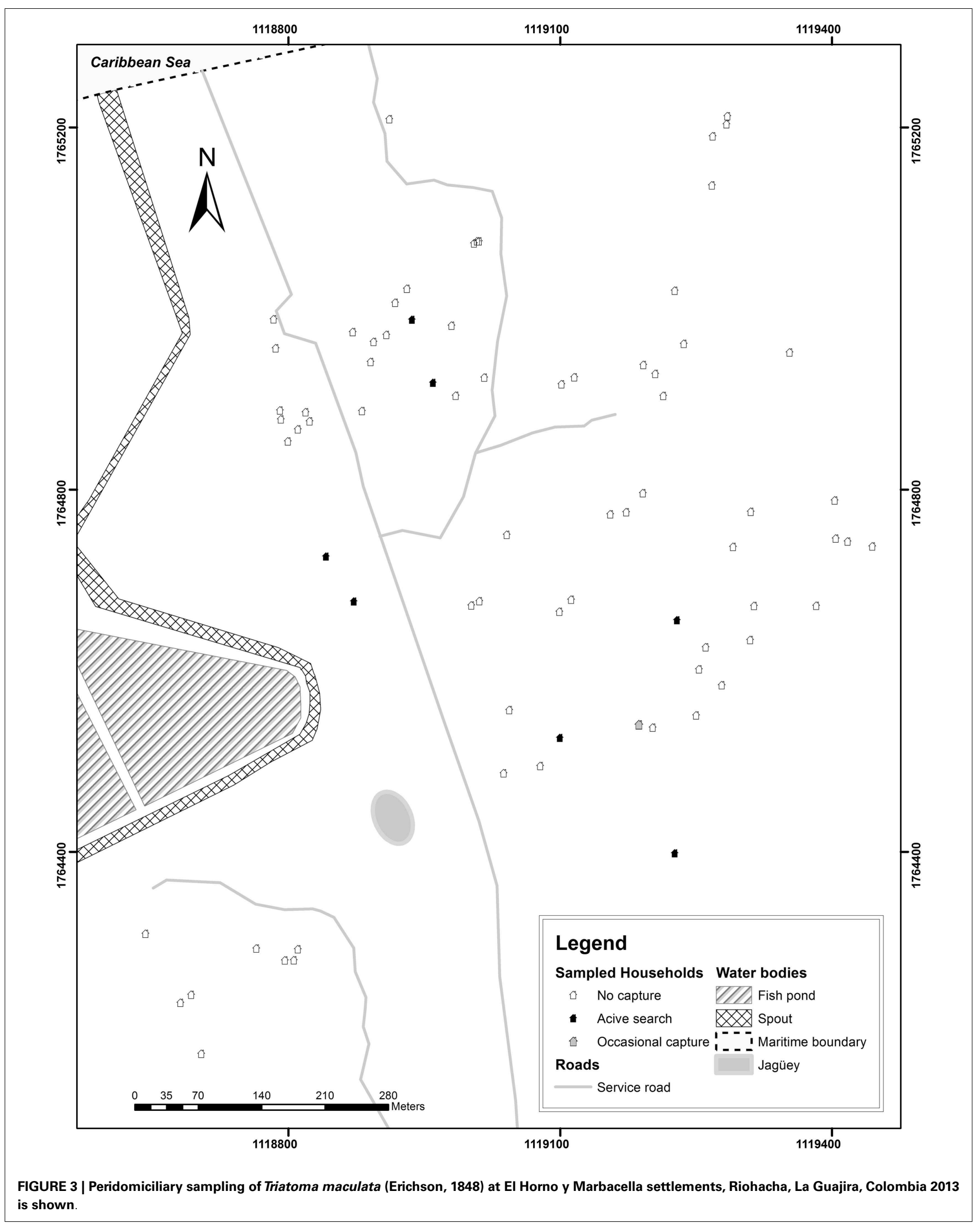


Table 1 | Sampling of Triatoma maculata (Erichson, 1848) Reduviidae: Triatomini using different trapping methods of Marbacella and El Horno settlements, Riohacha, La Guajira, Colombia 2013.

\begin{tabular}{|c|c|c|c|c|c|c|c|c|c|c|c|c|c|c|c|c|c|c|c|c|c|}
\hline \multirow[t]{4}{*}{ Capture method } & \multirow{4}{*}{$\begin{array}{l}\text { Positive } \\
\text { housing }\end{array}$} & \multicolumn{10}{|c|}{ Marbacella } & \multicolumn{10}{|c|}{ El Horno } \\
\hline & & \multicolumn{5}{|c|}{ Indoor } & \multicolumn{5}{|c|}{ Outdoor } & \multicolumn{5}{|c|}{ Indoor } & \multicolumn{5}{|c|}{ Outdoor } \\
\hline & & \multicolumn{3}{|c|}{$A$} & \multirow[t]{2}{*}{$N$} & \multirow[t]{2}{*}{$\boldsymbol{R}$} & \multicolumn{3}{|c|}{$A$} & \multirow[t]{2}{*}{$N$} & \multirow[t]{2}{*}{$\boldsymbol{R}$} & \multicolumn{3}{|c|}{$\boldsymbol{A}$} & \multirow[t]{2}{*}{$N$} & \multirow[t]{2}{*}{$\boldsymbol{R}$} & \multicolumn{3}{|c|}{$\boldsymbol{A}$} & \multirow[t]{2}{*}{$N$} & \multirow[t]{2}{*}{$\boldsymbol{R}$} \\
\hline & & $\theta$ & 9 & i & & & $\theta$ & 辛 & i & & & $\theta$ & 古 & $\mathbf{i}$ & & & $\boldsymbol{r}$ & 9 & i & & \\
\hline Active search & 14 & 1 & 0 & 4 & 1 & 2 & 6 & 6 & 0 & 7 & 2 & 2 & 1 & 0 & 0 & 6 & 1 & 0 & 1 & 55 & 5 \\
\hline Occasional capture & 2 & 4 & 2 & 0 & 0 & 0 & 4 & 3 & 0 & 0 & 0 & 0 & 0 & 0 & 0 & 0 & 0 & 0 & 0 & 0 & 0 \\
\hline Maria biosensors & 0 & 0 & 0 & 0 & 0 & 0 & 0 & 0 & 0 & 0 & 0 & 0 & 0 & 0 & 0 & 0 & 0 & 0 & 0 & 0 & 0 \\
\hline
\end{tabular}

$A$, adults; $i$, indeterminate sex; $N$, nymphs; $R$, exuviae of nymphs and adult triatomines bugs vestiges.

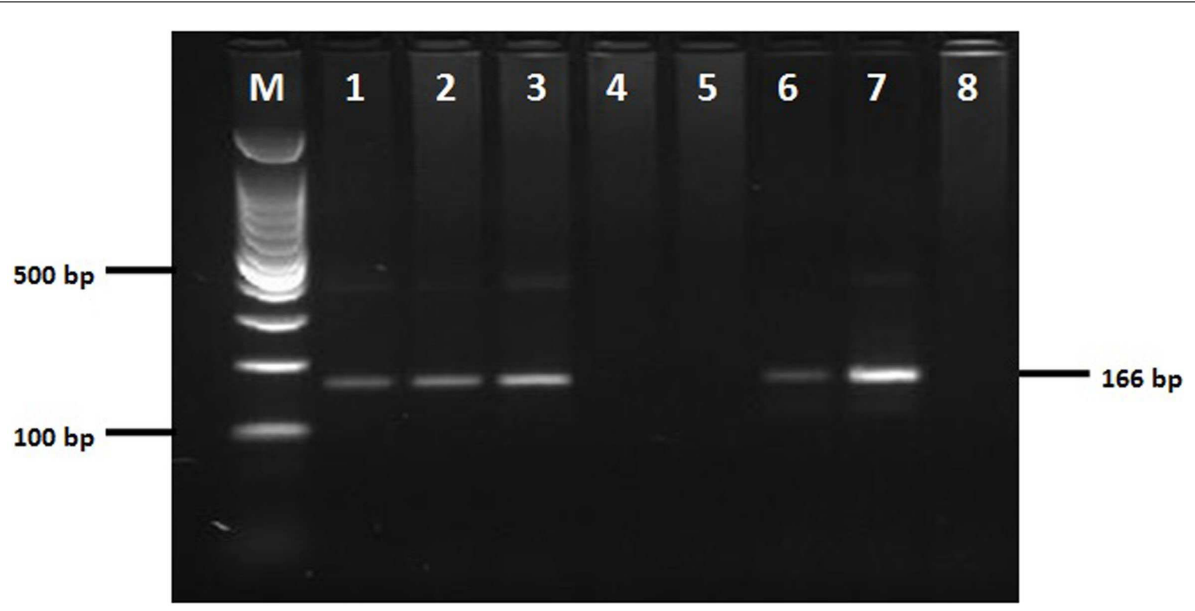

FIGURE 4 | Detection of DNA of Trypanosoma cruzi in insects Triatoma maculata by amplification of $T$. cruzi nuclear repetitive region-specific. Lanes 1-8 are amplification products of tandem repeat satellite region from T. cruzi (166 bp). Lanes 1-3: positive samples of
Triatoma maculata (166 bp). Lanes 4-5: negative samples of Triatoma maculata. Lanes 6-7: positive controls of T. cruzi (166 bp) Lane 8: negative control. Electrophoresis on a $2 \%$ agarose gel visualized by staining with gel red 100-bp weight marker.

Table 2 | Vector indices of Triatoma maculata (Erichson, 1848) Reduviidae: Triatomini in Marbacella and El Horno settlements, Riohacha, La Guajira, Colombia.

\begin{tabular}{|c|c|c|c|c|c|c|c|c|c|c|c|c|c|c|}
\hline \multirow[t]{3}{*}{ Settlements } & \multirow{3}{*}{$\begin{array}{l}\text { Housing } \\
\text { inspected }\end{array}$} & \multirow{3}{*}{$\begin{array}{l}\text { Positive } \\
\text { housing }\end{array}$} & \multicolumn{6}{|c|}{ Collection insects } & \multirow{3}{*}{$\begin{array}{l}\text { II } \\
(\%)\end{array}$} & \multirow{3}{*}{$\begin{array}{l}\text { PI } \\
(\%)\end{array}$} & \multirow{3}{*}{$\begin{array}{l}\text { HC } \\
(\%)\end{array}$} & \multirow{3}{*}{$\begin{array}{l}\text { VI } \\
(\%)\end{array}$} & \multirow{3}{*}{$\begin{array}{l}\text { VD } \\
(\%)\end{array}$} & \multirow[t]{3}{*}{ DI } \\
\hline & & & \multicolumn{3}{|c|}{ Indoors } & \multicolumn{3}{|c|}{ Outdoors } & & & & & & \\
\hline & & & $\mathbf{N}$ & A & $\mathbf{R}$ & $\mathbf{N}$ & A & $\mathbf{R}$ & & & & & & \\
\hline Marbacella & 51 & 11 & 1 & 11 & 2 & 7 & 19 & 2 & 13.7 & 11.8 & 9.1 & 43.5 & 21.6 & 0.8 \\
\hline
\end{tabular}

A, adults; N, nymphs; R, exuviae of nymphs and adult triatomines bugs vestiges; II, intradomiciliary infestation indice; Pl, peridomiciliary infestation indice; HC, household colonization indice; VI, vector infection indice; VD, vector dispersion indice; DI, vector density indice.

In Colombia, T. maculata was found naturally infected by $T$. cruzi with high infection indices between 50 and $72 \%$; intradomiciliar infestation indices between 13 and $20 \%$, and $38.3 \%$ colonization in the municipalities of Talaigua Nuevo and Mompox, department of Bolívar $(9,10)$. These studies demonstrate the ability of $T$. maculata to infest and colonize stable artificial ecotopes as human habitat and potential efficiency as a vector of Chagas disease. 
In this study, exuviae, nymphs, and adults of T. maculata were found within households of both indigenous settlements, with colonization indices of 9.1\% for Marbacella and 20\% for El Horno, which could be suggesting infestation and colonization processes inside the housing. In addition, indices of natural infection with $T$. cruzi between 36 and $43 \%$ are reported, which is an important risk factor for the inhabitants of the Wayúu ethnic group in both communities. In contrast to these results, in San Miguel and Xaguas parishes in the Lara State, Venezuela, albeit with similar indices of infestation and colonization, low indices of T. cruzi infection were recorded, so that the epidemiological significance of T. maculata depends on the environmental, ecological, and socio-cultural factors characteristic of each geographical area $(27,28,34)$.

In domiciled triatomines, a relationship is established between housing characteristics and the type of construction material, distribution of peridomestic annexes and finishes of ceilings, walls and floors, as well as socio-cultural practices of its inhabitants with respect to the population distribution and development of triatomine species in homes (35-37). This is of particular importance in both indigenous settlements because due to the physical characteristics of housing (mainly bahareque walls and sand floor) and the use of intradomiciliary spaces as places of poultry refuge and nesting, intrusion, and colonization processes may be assisted by passive transport factors and optimal conditions for the biological development of the species $(36,37)$.

Ignorance of the local health authorities and communities about the presence and levels of infestation, colonization, and natural T. cruzi infection with T. maculata and the risk it poses to the people, particularly children, makes it important to strengthen entomological surveillance in the area, together with participation strategies and community action to establish early warning systems for the recognition of the different stages of the insect and the early diagnosis of domiciliation processes of T. maculata.

With an aim to the interruption of intradomiciliar transmission of T. cruzi with triatomine, Colombia has defined control schemes based on the application of synthetic chemical insecticides in areas of infestation (4). It is important to understand the ecological, biological, and socio-cultural context where vector transmission is occurring and involve affected communities so that strategies for prevention, monitoring, and effective and sustainable control are jointly constructed. The ecobiosocial approach through transdisciplinary research, systems thinking, community participation, and environmental sustainability proves useful for the design, implementation, and evaluation of control strategies appropriate to the ecological, social, and cultural context (38-40). It is suggested to extend these studies in other indigenous settlements, as well as in the urban area of Riohacha because it is possible to find housing conditions and natural ecotopes with appropriate habitats described for this species, which, together with the significant human density in this capital, constitutes a significant risk for Chagas disease. Although in the present study the active search by technical personnel and the community was the most effective method to found exuviae, nymphs, and adults of triatomine, it is important to include in entomological surveillance other strategies based on biosensors $(24,41)$ and fumigant canisters (41-43) to improve the sensibility of results and its impact in public health policies. In particular, the fumigant canister could be used both to get an idea about infestation indices and to control the insects simultaneously. Nevertheless, it is necessary to inform the community about the risks, benefits, and consequences of the use of insecticide in the fumigant canister.

In conclusion, this is the first report of $T$. maculata naturally infected with T. cruzi in the municipality of Riohacha and its geographic distribution in the department of La Guajira has expanded. T. maculata was found mainly associated with peridomestic spaces (chicken coops and pens), although indices of intradomiciliar infestation, colonization, and natural infection by $T$. cruzi were found, posing a risk to the Wayúu community of El Horno and Marbacella indigenous settlements. The ethnic and cultural importance of the Wayúu community and the burden that the disease involves in terms of disability and reduced life expectancy (4), makes it necessary for the results to be contextualized as a serious public health problem.

\section{AUTHORS CONTRIBUTION}

Edith Natalia Gómez-Melendro: development of field and laboratory component. Participation in the preparation of the scientific paper. Diana Carolina Hernández-Castro: development laboratory component and participation in the development of the scientific paper. Catalina Gonzalez-Uribe: principal investigator and participation in the development of the scientific paper. Helena Brochero: principal investigator, coordination of the entomological component and participation in the development of the scientific paper.

\section{ACKNOWLEDGMENTS}

We would like to acknowledge the community members and leaders of the indigenous settlements at El Horno and Marbacella who generously agreed to participate in this project; the officials of the Departmental Health Office of La Guajira for accompanying us in the field; Aura Sotelo for the entomological material processing in the laboratory. Finally, we would like to thank Leonardo Buitrago for developing the maps with geographic information used in this project. Financing: this study was funded by the Administrative Department of Science, Technology and Innovation, COLCIENCIAS, under the project "Co-construction of an Ecohealth strategy for the prevention, surveillance, and control of vector-borne diseases in indigenous communities in Colombia," which is part of the "Reduced morbidity and mortality of vector-borne diseases: research program with an ecosystem approach to the prevention and control of malaria and dengue in Colombia" program run by the Temporary Union between the Fundación Santa Fe de Bogotá and the Fundación SALUTIA. The study also received funding from the International Development Research Centre. The Health Office of the department of La Guajira funded the support of staff in field activities.

\section{REFERENCES}

1. Guhl F, Angulo V, Restrepo M, Nicholls S, Montoya R. Estado del arte de la enfermedad de Chagas en Colombia y estrategias de control. Biomédica (2003) 23:31-7.

2. Moncayo A. Chagas disease: current epidemiological trends after the interruption of vectorial and transfusional transmission in the Southern Cone countries. Mem Inst Oswaldo Cruz (2003) 98:577-91. doi:10.1590/S007402762003000500001 
3. Pan American Health Organization (PAHO). Health in the Americas. Washington, DC: Pan American Health Organization (2002).

4. Ministerio de Salud y Proteccion Social, Instituto Nacional de Salud (INS), Organización Panamericana de la Salud (OPS). Gestión Para la Vigilancia Entomólogica y Control de la Transmisión de la Enfermedad de Chagas. (2010). Available at: http://www.minsalud.gov.co/Documents/Salud $\% 20 \mathrm{P} \%$ C3\%BAblica/Ola\%20invernal/Entomologica\%20Chagas.pdf

5. Dias J, Schofield C. The evolution of Chagas disease (American Trypanosomiais) control after 90 years since Carlos Chagas Discovery. Mem Inst Oswaldo Cruz (1999) 94:103-22. doi:10.1590/S0074-02761999000700011

6. Lent H, Wygodzinsky P. Revision of the Triatominae (Hemiptera, Reduviidae), and their significance as vectors of Chagas disease. Bull Am Museum Nat Hist (1979) 163:123-520.

7. Guhl F, Aguilera G, Pinto N, Vergara D. Actualización de la distribución geográfica y ecoepidemiología de la fauna de triatominos (Reduviidae: Triatominae) en Colombia. Biomédica (2007) 27:143-62. doi:10.7705/biomedica.v27i1. 258

8. Molina JA, Gualdrón LE, Brochero HL, Olano VA, Barrios D, Guhl F. Distribución actual e importancia epidemiológica de las especies de triatominos (Reduviidae: Triatominae) en Colombia. Biomédica (2000) 20:344-60. doi:10.7705/biomedica.v20i4.1078

9. Cortés LA, Suárez HA. Triatominos (Reduviidae: Triatominae) en un foco de enfermedad de Chagas en Talaigua Nuevo (Bolívar, Colombia). Biomédica (2005) 25:568-74. doi:10.7705/biomedica.v25i4.1383

10. Cantillo-Barraza O, Gómez-Palacio A, Salazar D, Mejía-Jaramillo AM, Calle J, Triana O. Distribución geográfica y ecoepidemiología de la fauna de triatominos (Reduviidae: Triatominae) en la Isla Margarita del departamento de Bolívar, Colombia. Biomédica (2010) 30:382-9. doi:10.7705/biomedica.v30i3.272

11. Montilla M, Soto H, Parra E, Torres M, Carrillo P, Lugo L, et al. Infestación por triatominos en comunidades indígenas de Valledupar, Colombia. Rev Saúde Pública (2011) 45:773-80. doi:10.1590/S0034-89102011005000037

12. Vásquez C, Robledo S, Callle J, Triana O. Identificación de nuevos escenarios epidemiológicos para la enfermedad de Chagas en la región Momposina, norte de Colombia. Biomédica (2013) 33:4-10. doi:10.7705/biomedica.v33i4.836

13. Dib J, Barnabe C, Tibayrenc M, Triana O. Incrimination of Eratyrus cuspidatus (Stal) in transmission of Chagas disease by molecular epidemiology analysis of Trypanosoma cruzi isolates from a geographically restricted area in the north of Colombia. Acta Trop (2009) 3:237-42. doi:10.1016/j.actatropica.2009. 05.004

14. Wolf M, Castillo D. Evidencias de domesticación y aspectos biológicos de Panstrongylus geniculatus (Latreille, 1811) (Hemiptera: Reduviidae). Acta Entomol Chil (2000) 24:77-83.

15. Hernández DC, León CM, Valencia-Hernández C, Vera MJ, Cucunubá ZM, Flórez A, et al. Molecular tracking of Chagas disease outbreaks by possible oral transmission route in Colombia. 13th International Congress of Parasitology. México: (2014). Available at: http://checkmein.com.mx/icopa2014/files/ abstracts/36/pdf/2575.pdf

16. Corredor A, Santacruz M, Páez S, Guatame LA. Vectores. In: Buitrago B, Carmona F, Hernández C, Toro G, Vernot J, Wasserman M editors. Distribución de los Triatominos Domiciliarios y Extradomiciliarios en Colombia. Bogotá, DC: Instituto Nacional de Salud (1990). p. 117-20.

17. Departamento Administrativo Nacional de Estadística (DANE). Estudios Postcensales No. 7 - Proyecciones Nacionales y Departamentales de Población 20052020. Bogotá, DC: Departamento Administrativo Nacional de Estadística (2009).

18. Holdridge L, Grenke W, Hatheway W, Liang T, Tosi T. Forest Environments in Tropical Life Zones, A Pilot Study. Oxford: Pergamon Press (1971).

19. Instituto de Investigación de Recursos Biológicos Alexander von Humboldt (IAvH), Instituto de Hidrología, Meteorología y Estudios Ambientales (IDEAM), Instituto de Investigaciones Ambientales del Pacífico (IIAP), Instituto de Investigaciones Marinas y Costeras José Benito Vives de Andréis (INVEMAR), Instituto Amazónico de Investigaciones Científicas (SINCHI). Estado del Medio Ambiente y de los Recursos Naturales. In: López C, Toro M, editors. Informe del Estado del Medio Ambiente y de los Recursos Naturales Renovables 2010, Bogotá D.C: Instituto de Hidrología, Meteorología y Estudios Ambientales (2011). p. 73-80.

20. Espinal LS. Geografia ecologica del departamento de Antioquia (Zonas de vida (formaciones vegetales) del departamento de Antioquia). Rev Fac Nac Agron Medellin (1985) 38:24-39.
21. Murphy PG, Lugo AE. Ecology of tropical dry forest. Annu Rev Ecol Syst (2007) 17:67-88. doi:10.1146/annurev.es.17.110186.000435

22. Pizano C, Cabrera M, García H. El Bosque Seco Tropical en Colombia; Generalidades y Contexto. In: Pizano C, García H. editors. El Bosque Seco Tropical en Colombia. Bogotá DC: Instituto de Investigación de Recursos Biológicos Alexander von Humboldt (2014). p. 37-47.

23. Instituto de Investigación de Recursos Biológicos Alexander von Humboldt (IAvH). Caracterización Ecológica de Cuatro Remanentes de Bosque Seco Tropical de la Región Caribe Colombiana. Grupo de Exploraciones Ecológicas Rápidas IAvH Villa de Leyva: Instituto de Investigación de Recursos Biológicos Alexander von Humboldt (1997). p. 76.

24. Centro Internacional de Entrenamiento e Investigaciones Médicas (CIDEIM). Manual de Entomología médica Para Investigadores de América Latina. Travi B, Montoya-Lerma J, editors. Cali: Centro Internacional de Entrenamiento e Investigaciones Médicas (1994).

25. Ramírez J, Guhl F, Umezawa E, Morillo C, Rosas F, Marin-Neto J, et al. Evaluation of adult chronic Chagas heart disease diagnosis by molecular and serological methods. J Clin Microbiol (2009) 47:3945-51. doi:10.1128/JCM.01601-09

26. Silveria AC, Sanches O. Guía para muestreo de actividades de vigilancia y control vectorial de la enfermedad de Chagas. (2003). 41 p. Available at: http: //www.bvsops.org.uy/pdf/chagas09.pdf

27. Bonfante-Cabarcas R, Rodríguez-Bonfante C, Vielma BO, García D, Mogollón Saldivia A, Aldana E, et al. Seroprevalencia de la infección por Trypanosoma cruzi y factores asociados en un área endémica de Venezuela. Cad Saúde Pública (2011) 27:1917-29. doi:10.1590/S0102-311X2011001000005

28. Rojas ME, Várquez P, Villarreal MF, Velandia C, Vergara L, Morán-Borges YH, et al. Estudio seroepidemiológico y entomológico sobre la enfermedad de Chagas en un área infestada por Triatoma maculata (Erichson 1848) en el centrooccidente de Venezuela An entomological and seroepidemiological study of Chagas disease in an area in centr. Cad Saúde Pública (2008) 24:2323-33. doi:10.1590/S0102-311X2008001000013

29. Parra-Henao G, Angulo V, Jaramillo N, Restrepo M. Triatominos (Hemiptera: Reduviidae) de la Sierra Nevada de Santa Marta, Colombia. Aspectos epidemiológicos, entomológicos y de distribución. Rev CES Med (2009) 23:17-26. Available from: http://revistas.ces.edu.co/index.php/medicina/article/view/996/642

30. D'Alessandro A, Barreto P, Thomas M. Nuevos registros de triatominos domiciliarios y extradomiciliarios en Colombia. Colomb Med (1981) 12:75-85.

31. Luitgards-Moura JF, Vargas AB, Almeida CE, Magno-Esperança G, Agapito-Souza R, Folly-Ramos E, et al. A Triatoma maculata (Hemiptera, Reduviidae, Triatominae) population from Roraima, Amazon region, Brazil, has some bionomic characteristics of a potential Chagas disease vector. Rev Inst Med Trop Sao Paulo (2005) 47:131-7. doi:10.1590/S003646652005000300003

32. Pifano F. La epidemiología de la enfermedad de Chagas en Venezuela. Arch Venez Med Trop Parasitol Med (1973) 5:171-84.

33. Schofield C, Diotautil L, Dujardin J. The process of domestication in triatominae. Mem Inst Oswaldo Cruz (1999) 94:375-8. doi:10.1590/S007402761999000700073

34. Guhl F, Pinto N, Aguilera N. Sylvatic triatominae: a new challenge in vector control transmission. Mem Inst Oswaldo Cruz Rio Janeiro (2009) 104:71-5. doi:10.1590/S0074-02762009000900012

35. Bustamante DM, Monroy C, Pineda S, Rodas A, Castro X, Ayala V, et al. Risk factors for intradomiciliary infestation by the Chagas disease vector Triatoma dimidiata in Jutiapa, Guatemala. Cad Saúde Pública, Rio Janeiro (2009) 25:583-92. doi:10.1590/S0102-311X2009001300008

36. Castillo D, Wolf M. Aspectos del comportamiento de los triatominos (Hemiptera: Reduviidae), vectores de la enfermedad de Chagas. Biomédica (2000) 20:59-64. doi:10.7705/biomedica.v20i1.1048

37. Wolf M, Castillo D, Uribe J, Arboleda JJ. Tripanosomiasis americana: determinación de riesgo epidemiológico de transmisión en el municipio de Amalfi, Antioquia. IATREIA (2001) 14:111-21. Available from: http://aprendeenlinea. udea.edu.co/revistas/index.php/iatreia/article/view/3797

38. Carrasquilla G. An ecosystem approach to malaria control in an urban setting. Cad Saúde Pública (2001) 17:171-9. doi:10.1590/S0102-311X2001000700027

39. Lebel J. Salud. Un Enfoque Ecosistémico. Bogotá: Alfaomega (2005).

40. Charron DF. Ecosalud: Orígenes y enfoque. In: Charron DF editor. La investigación de Ecosalud en la práctica. Aplicaciones Innovadoras de un Enfoque Ecosistémico Para la Salud. Madrid: Plaza y Valdes. p. 42-6. 
41. Oliveira Filho AM. Uso de nuevas herramientas para el control de triatominos en diferentes situaciones entomológicas en el continente americano. Rev Soc Bras Med Trop (1997) 30:41-6. doi:10.1590/S0037-86821997000100008

42. Pinto JC, Zerba E. Emprego de pote fumígeno para proteção de insetário e sua ação residual contra triatomíneos, em condições de laboratório. Rev Soc Bras Med Trop (2001) 34:507-10. doi:10.1590/S0037-86822001000600002

43. World Health Organization (WHO). Triatomine bugs. In: Rozendaal JA, editor. Vector Control: Methods for Use by Individuals and Communities. Geneva: World Health Organization. (1997). p. 230-2. Available from: http://www.who. int/water_sanitation_health/resources/vectorcontrol/en/

Conflict of Interest Statement: The authors declare that the research was conducted in the absence of any commercial or financial relationships that could be construed as a potential conflict of interest.
Received: 30 June 2014; accepted: 18 October 2014; published online: 10 November 2014.

Citation: Gómez-Melendro EN, Hernández C, González-Uribe C and Brochero $H$ (2014) First record of Triatoma maculata (Erichson, 1848) (Hemiptera: Reduviidae: Triatomini) in the municipality of Riohacha, La Guajira - Colombia. Front. Public Health 2:219. doi: 10.3389/fpubh.2014.00219

This article was submitted to Epidemiology, a section of the journal Frontiers in Public Health.

Copyright () 2014 Gómez-Melendro, Hernández, González-Uribe and Brochero. This is an open-access article distributed under the terms of the Creative Commons Attribution License (CC BY). The use, distribution or reproduction in other forums is permitted, provided the original author(s) or licensor are credited and that the original publication in this journal is cited, in accordance with accepted academic practice. No use, distribution or reproduction is permitted which does not comply with these terms. 